\title{
Strengthening Students' Historical Awareness in History Learning in High School Through Inquiry Method
}

\author{
Yunitasari Rusvitaningrum*; Leo Agung S; Sudiyanto Sudiyanto \\ Faculty of Teacher Training and Education, Universitas Sebelas Maret, Indonesia \\ Email: lunetaecha18@gmail.com
}

http://dx.doi.org/10.18415/ijmmu.v5i5.446

\begin{abstract}
This article focuses on strengthening students' historical awareness in learning history in high school through the inquiry method. The purpose of this study was to identify the strengthening of students' historical awareness through the inquiry method. Data is obtained through documents of books, journals, theses, proceedings, and websites that relate to the object of research and then analyzed with text analysis techniques. The results showed the inquiry method was very helpful to make history teaching more interesting, showed students that the facts existed and also gave students the opportunity to actively participate in history lessons and students were encouraged to act actively looking for answers to the problems they faced and draw conclusions itself through a process of scientific thinking that is critical, systematic and logical so that historical awareness that had previously grown stronger.
\end{abstract}

Keywords: History; Historical Awareness; History Learning; Inquiry Method

\section{Introduction}

History has various meanings, In Arabic history comes from the word "syajarah" which means tree or syajarah which means to happen (Kuntowijoyo., 2005: 1). The word "syajaratun" or tree/ root/ offspring has the understanding that history as a sequence of origins of descent that has been continuous since the past; a lineage that has branches, from parents, children, great-grandchildren, and so on; and the development from one event to another on going basis according to the timeline (Arif., 2011).

Kartodirjo (1992: 14-15) divides the notion of history in two different perspectives: objectively and subjectively. Objectively history is in the event of the event itself, namely the historical process in its actualization, regardless of any subject. Whereas subjectively history is a building compiled by historians as a story about a particular event that occurred in the past.

One of the important meanings of history is to devote the experiences of the people in the past, which at times can be considered by the community in solving the problems they face. Without history, people will not be able to develop ideas about the consequences of what is done in the reality of life now and in the future, framed in a historical consciousness. The value of history is that history has taught what people have done. History as a science of the origin and development of events that have taken place also 
plays an important role in social studies learning because history is a collective human experience where history has the meaning of lessons and life experiences so that makes humans wiser and more humanistic and has a strong historical awareness.

Historical awareness can be seen from the aspect of love for the homeland or nationalism and patriotism that reflects historical awareness. The concept of historical awareness that is applied to students will make students verbally state that they have a sense of patriotism, nationalism, and patriotism. The concept of historical awareness is translated simply, for example the behavior of students when singing a major Indonesian song, the attitude of students when attending a flag ceremony, the discipline of students entering the class and following the apples, students 'responses to the assignments given, explicitly stated that students' historical awareness still needs to be developed.

Today we are faced with the problem of low historical awareness among students and the younger generation. We find this phenomenon in the practice of learning history in schools, including during the flag ceremony every Monday, there are still students who are late in attending the ceremony, not standing tall when the position is ready, scratching their bodies when the red and white flag is raised, and not seriously singing the song Indonesia Raya, some are disturbing their friends during the flag ceremony. In the classroom also shows students' historical awareness is still weak, for example there are still classes that do not have photos of heroes, country symbols, and maps of Indonesia. Do not place the flag in front of the class, do not discipline to enter the class, do not timely complete the task, do not use good and correct Indonesian when expressing opinions (still affected by certain regional dialects). The lack of students' historical awareness also proved by the presence of students who did not idolize national hero figures. Most students idolize singers and actors / actresses both from within and outside the country. It is even difficult to find students who know and know about local fighters.

Many factors cause students' historical awareness to be lacking, among others; 1) recognized global life tendencies that tend to ignore past values; 2) subject matter content that is not relevant to the formation of historical awareness; 3) a system that does not support the development of historical awareness, for example social-based subjects (social studies and history) tends to be ignored because it is not used as a National Examination subject so it is underestimated by students; 4) student's motivation and orientation that are too pragmatic, namely assuming that the exact subjects are the most superior because they can provide greater benefits than social based lessons; and 5) teacher factors also greatly influence the low level of students' historical awareness.

Before questioning the learning methods and strategies, there are actually other issues that must be shared with attention, namely teaching materials and reference sources that are used as references. We are often faced with controversial historical problems, especially contemporary history, which are different from textbooks in schools. Between history that is remembered, history made, and history found often overlaps and surfaces simultaneously.

Fostering historical awareness for students and the younger generation must be done in creative and innovative ways so that they are easily accepted. One of them is to use the inquiry method. This method emphasizes in obtaining information is by making observations to find answers or solve problems to the question or formulation of the problem by using critical and logical thinking skills that make historical views, thoughts or constructions as planned efforts to understand the past in the environment can function well so that it can be used to measure and determine human attitudes within its historical framework. 


\section{Methodology}

This study uses the literature study research method by collecting data both from document books, international and national journals, thesis, proceedings articles, and websites related to the research object and then analyzed by text analysis techniques.

\section{Results and Discussion History Learning in High Schools}

Learning history is a combination of learning and teaching activities in which to learn about past events that are closely related to the present. Widja's opinion (1989) can be concluded if the history subject is a field of study related to the facts in history but still pay attention to the objectives of education in general.

History learning does not specialize in studying facts in history as a science but a combination of history and educational goals in general. Nevertheless, history learning seeks to show historical facts objectively even though it remains within a historical factual framework that is consistent with the purpose of education itself.

The purpose of learning in school is so that students gain the ability to think historically and understand history. Through history learning students are able to develop competencies to think chronologically and have knowledge of the past that can be used to understand and explain the process of development and change of society and socio-cultural diversity in order to discover and foster national identity in the midst of the life of the world community. History learning also aims to make students aware of the diversity of life experiences in each community and the different perspectives on the past to understand the present and build knowledge and understanding to deal with the future (Depdiknas., 2006).

At the high school level, the learning objectives of history are: 1) Encourage students to think critically analytically in utilizing knowledge about the past to understand present and future lives; 2) Understanding that history is part of everyday life; 3). Develop intellectual abilities and skills to understand the process of change and community sustainability (Pusat Kurikulum., 2002).

In the process of learning history there are two aspects that must be considered by the teacher, namely mastering the facts and developing historical thinking habits. Through the study of history students get a picture of the background of their present life, so learning about past events provides an understanding that there is continuity with the present life. This historical knowledge provides a comprehensive understanding of the development or trends of various nations. Thus, students gain an understanding of a broader life. For example, the occurrence of tensions between Islam and Christianity requires an understanding of patterns that have been formed since approximately 12 centuries ago. Similarly, history learning requires pressure on important issues that occur in the world as a basis for understanding world history. Developing historical thinking habits through comparative studies will enrich knowledge and analysis. Students make comparisons in terms of different patterns in the history of various traditions and cultures in the world.

\section{Inquiry Method in Learning History in High Schools}

The inquiry method is a learning method that emphasizes the learning process, activities, and creativity of students in acquiring knowledge, skills, values, and attitudes and applying them in daily life. Inquiry method according to Hanafiah (2009: 77) is a series of learning activities that involve maximally 
all the ability of students to search and investigate systematically, critically, and logically so that they can find their own knowledge, attitudes, and skills as a form of behavior change. While the inquiry method according to Subrata (2000: 54) suggests that the inquiry method encourages students to be actively involved in the generalization process and test hypotheses. According to Ratnawulan (2008: 23) argues that inquiry is a method that prepares students in situation 8 to conduct their own experiments widely in order to see what is happening, want to do something, ask questions, find their own answers, and connect one discovery with the finding's others, comparing what was found with what other students found.

In history learning, inquiry methods are used to build enthusiasm and activity in student learning. By prioritizing ways or concepts of critical thinking makes students more confident in intellectual activities. Inquiry is used to solve problems faced by students in history learning. Thorstone (1928) stated the most important thing in the inquiry is that students look for something to the level of "sure". Which level is achieved through data support, analysis, interpretation and verification.

The application of inquiry methods in history learning so that students become more active to find their own answers or knowledge through research, which is in accordance with the learning steps in curriculum 2013 that uses the scientific approach.

By using this method students can find their own stories about historical events through observation or research conducted by students by reading existing reference books, through discussions between friends so that if students find their own stories, the hope that the knowledge gained will be recorded longer in their memory, different if students get knowledge from their teacher.

\section{Inquiry Method as Strengthening Historical Awareness in History Learning}

As one of the varied learning methods, students' own problem solving is able to strengthen historical awareness that has previously grown. Because history teaches how to make choices, consider various opinions, also to bring various stories. History is a subject that also teaches manners because it creates humility in the face of limited human ability to know how wide human history is. History can provide wisdom for anyone who studies it. Bacon said history make man wise. History concerns continuity and change so that every human being can learn because humans certainly do not want to repeat mistakes in the past (Sam Wineburg., 2006).

According to Sartono Kartodirdjo (1992), history has a very close connection with education in general and national character education in particular. Through history, inheritance can be carried out from previous generations to present generations. From the inheritance of values that will foster historical awareness, which in turn can be used for the development of national character. If the past can be projected into the present, it can be found educational meaning in history.

The inquiry approach is part of the learning strategy to strengthen students' historical awareness because in the inquiry method there is an understanding of constructiveism, where according to this understanding students are trained to solve problems, find something useful for themselves, and wrestle with ideas not just to remember a set of facts, rules and concepts of a particular history. In inquiry the activeness of thinking students is more prioritized than just reproducing various information that has been conveyed by the teacher (Hartati., 2005: 8). Students learn more themselves to develop their creativity in solving problems and are truly positioned as subjects who are learning, while the position of teachers is only as a guide and facilitator in the learning process. The learning process must be seen as a stimulus that can challenge students to do learning activities. 
The inquiry method is very important to strengthen student's historical awareness because students' perceptions are very diverse about history. Isjoni (2007) suggests that teachers do not need to be reluctant to use various existing historical sources, including historical sources in the form of objects (images, monuments, inscriptions, buildings, artifacts, etc.) to extract the views of students about history. Because, interpreting and explaining history is no longer just having the belief that if you got the facts right, the conclusions would take care of themselves, but also realizing that dealing with historical sources means being prepared for a number of traps and traps (Isjoni., 2007). Learning history in schools requires learning design that is appropriate to the age and ability of students. In high school, history learning must be given critically; Why did something happen, what was the real event, and where was the incident going?

Historical awareness includes several aspects. First, knowledge of historical facts and their causality; second, filling our mind's nature with logic; third, increasing our conscience with wisdom and wisdom, to deal with the present and the future by learning and reflecting on past experiences. With so historical awareness is a mental attitude and state of mind which is the power to participate actively in the process of national dynamics. Through history we can use healthy thoughts, logic and imagination, and be careful in using meaningful historical sources.

Historical awareness is very important given that they are the nation's next generation who have a historical awareness attitude to secure, maintain, develop, and inherit culture. To support the strengthening of historical awareness, a variety of inquiry methods are needed because this method will help make history teaching more interesting, showing students the facts. This approach also gives students the opportunity to actively participate in history lessons so that students do not experience boredom and add new motivation and enthusiasm in learning history. The inquiry teaching approach is one type of teaching that relies on the principle of finding out-for yourself where this approach is designed to provide opportunities for students to develop their intellectual potential in the interwoven activities of their own to find something (M. Oemar., 125: 1984). Students are encouraged to act actively seeking answers to the problems they face and draw their own conclusions through a critical, systematic and logical scientific thinking process. Thus, historical awareness that has previously grown will be strengthened along with the use of effective methods in the concept of critical thinking. Students become more confident, encourage students to do intellectual activities in dealing with and solving problems must always analyze and handle information because with the strengthening of historical awareness it will form a sense of pride and love for the homeland and to develop a sense of love for the homeland must know the origin of history his own people.

\section{Conclusion}

In history learning, inquiry methods are used to build enthusiasm and activity in student learning. By prioritizing ways or concepts of critical thinking makes students more confident in intellectual activities. History has a very close connection with education in general and national character education in particular. Historical awareness is very important given because they are the next generation of the nation. To support the strengthening of historical awareness, a variety of inquiry methods are needed because this method is very helpful in making history teaching more interesting, showing students that the facts are there and also allowing students to actively participate in history lessons and students are encouraged to act actively. looking for answers to the problems they face and drawing their own conclusions through a critical, systematic and logical scientific thinking process. Thus, historical awareness that has previously grown will be strengthened along with the use of effective learning methods. 


\section{Acknowledgment}

Author would like to thank all those who have helped with journal writing, especially to Dr. Leo Agung S, M.Pd and Dr. Sudiyanto, M.Pd, who has taken the time to guide and correct journal writing by providing very constructive suggestions and criticisms.

\section{Reference}

Arif, Muhammad. (2011). Pengantar Kajian Sejarah. Bandung: Yrama Wydia.

Depdiknas. (2002). Pengembangan Kurikulum Berbasis Kompetensi II. Jakarta: Balitbang Pusat Kurikulum.

Depdiknas. (2006). Strategi Pembelajaran yang Mengaktifkan Siswa. Jakarta: Depdiknas.

Hanafiah, Nanang. Dan Cucu, Suhana. (2009). Konsep Strategi Pembelajaran. Bandung: PT. Refika Aditama.

Isjoni. (2007). Cooperative Learning: Efektivitas Pembelajaran Kelompok. Bandung: Alfabeta.

Kartodirjo, Sartono. (1992). Pendekatan Ilmu Sosial dalam Metodogi Sejarah. Jakarta: Gramedia.

Kuntowijoyo. (2005). Pengantar Ilmu Sejarah. Yogyakarta: Bentang Pustaka.

M. Oemar. H. (1984). Pedoman Administrasi Supervisi dan Bimbingan Siswa SPG. Bandung: Jur. Kurtek FIP-KIP.

Ratnawulan, E. (2008). Evaluasi Pembelajaran. Bandung: Pustaka Setia.

Sam Wineburg. (2006). Historical Thinking and Other Unnatural Acts; Charting the Future of Teaching the Past: University Press Audiobooks.

Subrata, Surya. (2000). Proses Belajar Mengajar Di Sekolah. Jakarta: Ardi Mahatya.

Thorstone. (1928). Attitudes can be measure; American Journal of Sociology. 33: 529-540.

Widja, I. Gde. (1989). Dasar-Dasar Pengembangan Strategi Serta Metode Pengajaran Sejarah. Jakarta: Depdikbud.

\section{Copyrights}

Copyright for this article is retained by the author(s), with first publication rights granted to the journal.

This is an open-access article distributed under the terms and conditions of the Creative Commons Attribution license (http://creativecommons.org/licenses/by/4.0/). 